\title{
*ASSOCIATION OF SOUTHEAST ASIAN INSTITUTIONS OF HIGHER LEARNING (ASAIHL)
}

Ratasastra Building 2

Chulalongkorn University

Bangkok 10330 (Thailand) 1956

Tel: (662) 251-6966

Fax: (662) 255-4441

President: Dr. José D. Villanueva

Secretary-General: Dr. Ninnat Olanvoravuth

The Association's membership comprises 120 institutions in Australia, Brunei,Canada, Hong-Kong, Indonesia, Japan, Malaysia, New Zealand, Philippines, Singapore, Sweden, Thailand and U.S.A. It also has Associate Members outside the region. ASAIHL aims to: promote the economic, cultural and social welfare of the people of Southeast Asia by means of educational co-operation and research programmes, fostering the cultivation of a sense of regional identity and interdependence and co-operating with other regional and international organizations; serve as a clearing-house for information; and providing opportunities for discussion and recognize distinctive academic achievements.
Principal publications: Newsletter; Handbook; Seminar Procceedings.

Les membres de l'Association des institutions d' enseignement supérieur de l'Asie du Sud-Est (ASAIHL) comprennent 120 institutions dans les pays suivants: Australie, Brunei, Canada, Etats-Unis, Hong Kong, Indonésie, Japon, Malaisie, Nouvelle-Zélande, Philippines, Singapour, Suède et Thailande. L' ASAIHL a également des membres associés dans d'autres régions du monde. L'Association a pour buts: de promouvoir le bien-être économique, culturel et social des peuples de l'Asie du Sud-Est en coopérant dans le domaine de l'éducation et en favorisant les activités de recherche; de cultiver un sens de l'identité régionale et d'interdépendance et de coopérer avec d'autres organisations régionales et internationales; de servir d'office central d'information; d'offrir des occasions de discussions et de reconnaître les distinctions universitaires.

Publications principales: "Newsletter"; "Handbook"; "Seminar Proceedings". 